\title{
A comparative study of soil-structure interaction in the case of frame structures with raft foundation
}

\section{Primerjalna analiza interakcije konstrukcije in tal na primeru skeletne konstrulkcije temeljene na plošči}

\author{
Balázs Móczár, Zsuzsanna Polgár, András Mahler* \\ Department of Engineering Geology and Geotechnics, Budapest University of Technology and Economics, Muegyetem rkp. 3., \\ HU-1111, Hungary \\ *mahler@mail.bme.hu
}

\begin{abstract}
Design and modelling of raft foundations and selecting the value of coefficient of vertical subgrade reaction are still actively discussed topics in geotechnical and structural engineering. In everyday practice, soil-structure interaction is mostly taken into account by using the theory of 'beam on elastic foundation', in which the soil is substituted by a certain set of coefficients of subgrade reaction. In this study, finite element analysis of a building was performed using a geotechnical software (Plaxis 3D), which is capable of modelling the subsoil as a continuum, and a structural software (Axis VM), which uses the concept of 'beam on elastic foundation'. The evaluation of the results and recommendations for everyday engineering practice are introduced in this paper.
\end{abstract}

Key words: raft foundation, settlement, finite element analysis, subgrade reaction

\section{Izvleček}

Načrtovanje in modeliranje temeljenja na plošči kot tudi primerna selekcija koeficientov za vertikalne reakcije temeljev so zelo aktualne teme, ki so predmet skupnega interesa geotehniških in gradbenih inženirjev. V vsakodnevni praksi je problem interakcije konstrukcije in tal pogosto obravnavan kot problem "nosilec (preklada) na elastičnem temelju", pri čemer so tla zamenjana s skupino vertikalnih reakcij temeljev. V članku je prikazana statična analiza skeletne konstrukcije $\mathrm{z}$ uporabo metode končnih elementov s pomočjo geotehniškega programa Plaxis 3D, ki omogoča modeliranje temeljnih tal kot kontinuuma in tudi z uporabo programa za statične izračune (Axis VM), v katerem je uveljavljen koncept "nosilec (preklada) na elastičnem temelju". Prispevek podaja oceno rezultatov primerjalne analize in zaključke oziroma uporabna priporočila za vsakodnevno inženirsko prakso.

Ključne besede: temeljenje na plošči, posedanje, metoda končnih elementov, vertikalne reakcije temeljev 


\section{Introduction}

Everyday use of finite element analysis in structural engineering creates the demand for easily available and usable information from the vast knowledge of soil-structure interaction. Expansion and refinement of this large amount of knowledge are facilitated by model analyses with special geotechnical software products and the increasingly used monitoring in large projects.

The goal of this study is to make soil-structure interaction more understandable through the parametric analysis of a given structure - a multistorey reinforced concrete frame with raft foundation - with geotechnical software that can model the behaviour of soil more accurately.

Office buildings, parking garages and residential buildings are often constructed on raft foundation. Accordingly, soil mass appears as a surface support in the model of the structure; thus, it can be considered a set of springs. In practice, distribution corresponding to the modified Winkler method is the most commonly used, whereby the coefficient of subgrade reaction equals the ratio of average bearing pressure and settlement in the characteristic point. Although this theory is very popular among structural engineers because it significantly simplifies the calculation of soil-structure interaction, the proper definition of the subgrade reaction is often very complicated. Many recommendations are available in the international literature [1-5], and several enhanced methods have been published lately [6-9]. A well-known drawback of the theory is that there is no shear transmission between the adjacent springs, thus subgrade reaction following a certain distribution may be necessary. A case study of a damaged raft foundation [10] had pointed out that simple elastic continuum calculation results are in much better agreement with the measured settlements than the calculated values using subgrade reactions.

This study aims to capture the important tendencies in the distribution of subgrade reaction by back-calculating its values from the results of three-dimensional geotechnical finite element analyses (i.e., continuum calculations). The results enable some recommendations for the better use of subgrade reaction calculations in everyday design.

\section{Problem statement}

The subject of this study was a symmetric eight-storey reinforced concrete frame structure on raft foundation lying on the ground surface with floor plan dimensions of $32 \mathrm{~m}$ x $32 \mathrm{~m}$, as well as the soil mass underneath it (Figure 1).

Modelling was carried out with the finite element software Plaxis 3D Foundation, which is capable of handling soil as continuum with nonlinear deformation properties, and the structure can be modelled as an assembly of columns and slabs.

Main parameters of the model:

- Storey height: $3 \mathrm{~m}$,

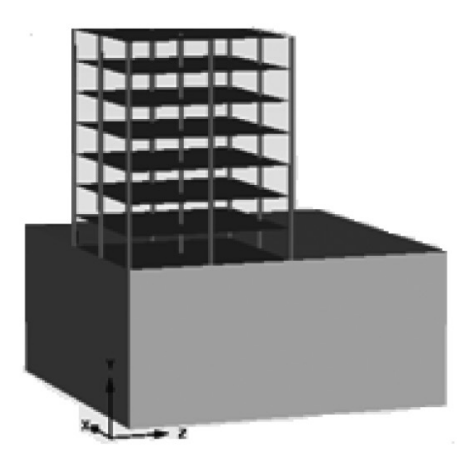

(a)

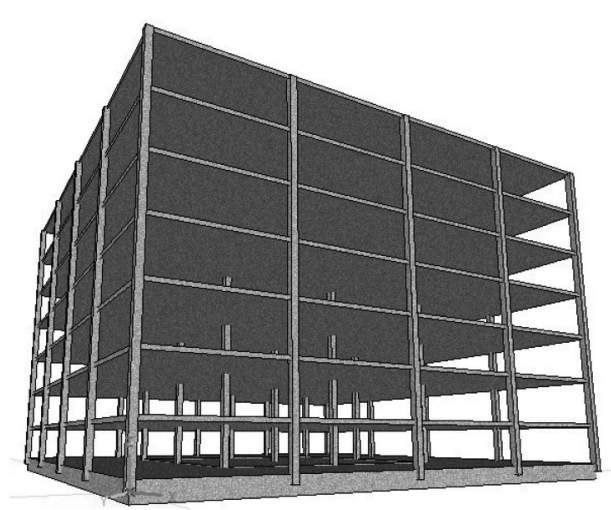

(b)

Figure 1: Geometry of the models: (a) geotechnical software and (b) structural software. 
Table 1: Soil properties.

\begin{tabular}{ccccc} 
Soil & Sandy gravel & Sand & Sandy silt & Clay (stiff) \\
\hline Unit weight, $\gamma_{\text {unsat }}\left(\mathrm{kN} / \mathrm{m}^{3}\right)$ & 19 & 18 & 19 & 19 \\
\hline Effective unit weight, $\gamma^{\prime}\left(\mathrm{kN} / \mathrm{m}^{3}\right)$ & 10 & 9 & 10 & 10 \\
\hline Angle of internal friction, $\varphi\left(^{\circ}\right)$ & 37 & 31 & 22 & 15 \\
\hline Cohesion, $c(\mathrm{kPa})$ & 0 & 0 & 20 & 40 \\
\hline Oedometer modulus, $E_{\text {oed }}(\mathrm{MPa})$ & 35 & 18 & 11 & 9 \\
\hline
\end{tabular}

- Distance of columns: $8 \mathrm{~m}$,

- Cross section of columns: $40 \mathrm{~cm} \mathrm{x} 40 \mathrm{~cm}$,

- Slab thickness: $25 \mathrm{~cm}$,

- Thickness of raft foundation: $40 \mathrm{~cm}-60 \mathrm{~cm}$ $-80 \mathrm{~cm}-100 \mathrm{~cm}$,

- Shear wall thickness: $0 \mathrm{~cm}$ or $25 \mathrm{~cm}$,

- Distributed load: intermediate slabs $3.5 \mathrm{kN} / \mathrm{m}^{2}$, roof slab $4.0 \mathrm{kN} / \mathrm{m}^{2}$,

- Element connections: slab-column connections are modelled as rigid components.

It should be emphasised that the geometry and dimensions of the structure were selected to be constant (except for the raft foundation thickness) and similar to those in real life, so they could represent constant structure stiffness, but their factual values have no importance in the study.

The analysis was performed assuming four different homogeneous soil types to examine the effects of different soil properties. The analysed soil types and their properties are summarised in Table 1 [11].

In order to investigate the effects of different parameters, a parametric study was carried out on two types of soil models: linear elastic-perfectly plastic (Mohr-Coulomb, MC) and nonlinear isotropic hardening (Hardening Soil, HS) material models $[12,13]$. In the study, effects of various soil properties, model depths (as the lower boundary of stresses taken into account; five different limit depth theories were applied: Egorov and Malikova [14], German standard: DIN1054, Earlier Hungarian standard: MSZ15004-1989, Széchy and Varga [15]), degrees of raft stiffness (40-60-80-100 cm thickness) and presence of shear wall at the ground floor were examined. Our focus was mainly directed towards the developing settlement of the structure, bearing pressure, bending moments in the raft and stresses in the slabs.

\section{Results}

On the basis of the analyses using reasonable combinations of the properties listed in Table 1 and interpretation of the results, the following conclusions could be drawn. These are partly similar to those of Széchy and Varga [15] and Dulácska et al. [16]:

- Combined behavior of soil structure is mainly influenced by the deformation parameters of the soil rather than by its shear strength parameters (so inadequate selection of shear strength parameters practically does not affect stress and strain conditions of the foundation. These parameters have strong influence on the ultimate limit state, which is rarely an issue);

- Limit depth, independently from soil type, has no effect on differential settlements and stresses, but it does strongly influence the absolute value of the settlement;

- If the soil's modulus of compressibility is lower, the relative settlement will be smaller because the raft distributes the excess stresses induced by point loads;

- More rigid raft foundation leads to smaller relative settlements due to point loads, and the distribution of vertical displacement approaches the typical shape of rafts loaded by solely distributed loads;

- In case of flexible rafts, vertical distribution of stresses is independent of soil type and its compressibility properties;

- By increasing the stiffness of the raft, stresses in granular and cohesive soils become increasingly different. In cohesive soils, higher negative, but smaller positive, stresses evolve, so the bending moment diagram shifts towards the negative bending moments while retaining its shape; 


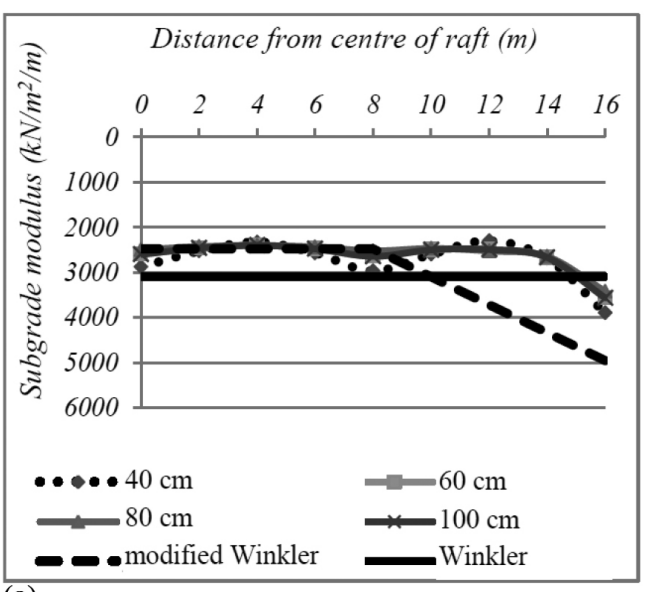

(a)

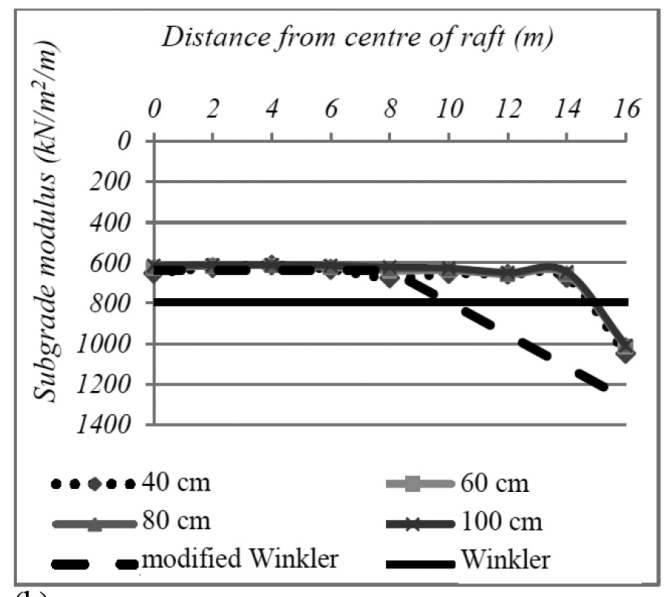

(b)

Figure 2: Coefficients of subgrade reaction in the middle cross section of the raft (a) for sandy gravel and (b) for clay.

- The thicker the raft, the higher will be the stresses in the foundation;

- Raft thickness has negligible influence on stresses in the slabs;

- At the ground floor, the enclosing shear wall only influences the stress and strain distribution of the raft near the wall;

- Compared to the solely frame structure, the effect of shear wall in the subgrade reaction is negligible.

Distribution of coefficient of subgrade reaction calculated from the geotechnical finite element software as the ratio of bearing pressure and settlement in each point is shown in Figure 2 for different degrees of raft thickness. Figure 2 also shows the Winkler and modified Winkler coefficients of subgrade reaction [17-19]. The recommendation of the modified Winkler method is to use $0.8 \mathrm{x}$ of the default value of subgrade modulus in the inner section of the raft, while near the edges (one-quarter of the total width), a linearly increasing value is proposed up to $1.6 \mathrm{x}$ of the default value. The default value was determined based on Kany's method by taking the ratio of average bearing pressure and settlement in the characteristic point. This theory is based on the determination of limit depth, which marks the theoretical lower boundary of soil mass that is compressed due to loading. After considering several different limit depth theories and based on practical experiences, a depth of $15 \mathrm{~m}$ was selected for this problem, for which the following results were obtained.

Based on these, the following conclusions can be drawn:
- Distribution of the coefficient of subgrade reaction is independent of soil type; it only influences the absolute value of the modulus (the softer the soil, the smaller will be the coefficient);

- Coefficient of subgrade reaction is not influenced by raft thickness for a given soil, except those of very flexible rafts;

- Coefficients determined with Plaxis software and the modified Winkler method (wherein the settlement was calculated based on the 'classical' method and with same limit depth) show good agreement with each other in the inner half of the raft;

- Unlike the modified Winkler method, bearing pressure and coefficient of subgrade reaction only increase in a narrow range near the edge (only in the one-sixteenth of the total width), and even in this range, their values do not reach the values recommended by the modified Winkler method;

- The coefficient of subgrade reaction can be approximated with a constant, except in the above-mentioned narrow range near the edges;

- The ratio between coefficients of subgrade reaction of the raft's outer and inner sections is the following for different soils (the stiffer the soil, the less is the difference):

- sandy gravel: 1.3-1.4

- sand: $1.3-1.4$

- sandy silt: $1.4-1.6$

- clay: $1.5-1.7$ 
Table 2: Average coefficients of subgrade reaction (in $\mathrm{kPa} / \mathrm{m}$ ).

\begin{tabular}{ccccc} 
Soil type $/$ method & Sandy gravel & Sand & Sandy silt & Clay (stiff) \\
\hline Winkler & 3097 & 1565 & 973 & 796 \\
\hline Plaxis & 3160 & 1524 & 926 & 724 \\
\hline Difference & $+2.0 \%$ & $-2.4 \%$ & $-4.8 \%$ & $-9.0 \%$ \\
\hline
\end{tabular}

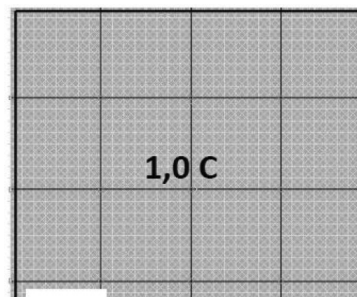

a)
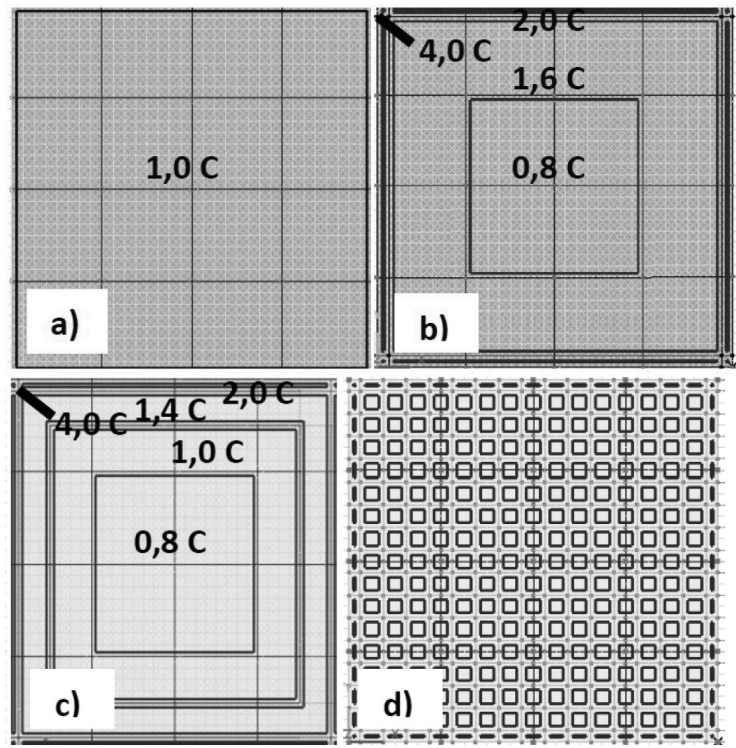

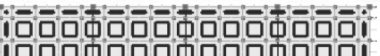

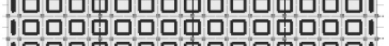

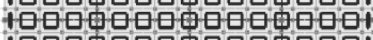

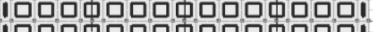

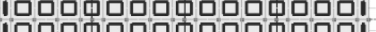
10吅吅吅呅

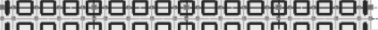

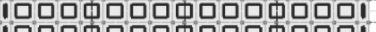

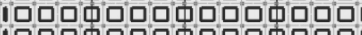
吅吅吅吅吅

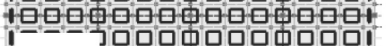

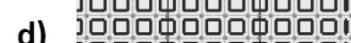

Figure 3: Analysed distributions of subgrade reaction: (a) Type 1, (b) Type 2, (c) Type 3 and (d) Type 4.

\section{Comparison}

Another aim of this study was to analyse the effect of different subgrade reaction distributions on the computed settlements and internal forces.

Three different approximate subgrade reaction distributions were examined, wherein the default value of the coefficient $(C)$, as mentioned previously, was defined as the ratio of average bearing pressure and settlement in the characteristic point. It should be noted that loads were included in the model with their design values in every calculation (for both stresses and settlements) as our goal was to analyse and present the tendency of the results.

In the analysis, the following distributions of the coefficient of subgrade reaction were considered (Figure 3):

- Type 1: The default coefficient $(C)$ is applied below the entire raft;

- Type 2: $0.8 \times C$ value in the inner $(16 \mathrm{~m})$ and $1.6 \times C$ value in the outer $(7 \mathrm{~m})$ sections of the raft as recommended by the modified Winkler method;

- Type 3: Type 2 was further modified to have better correspondence with the modified Winkler method: in the inner section, $0.8 \times C$ value was applied, but the outer zone was divided into two further zones: in the 4-m-wide zone closer to the inner section $1.0 \times C$ and, in the 3-m-wide zone at the edge, $1.4 \times C$ value were applied.

The latter two values were selected in such a way that the average value of the coefficient remains the same. Numerical analysis with distribution Types 2 and 3 showed that the structural software can give peak stresses at the edges and corners of the raft, contradicting the actual behaviour. The reason is that the software does not take into account the effect of stress distribution in these areas. Approximation can be improved by increasing the default value of the coefficient of subgrade reaction: developers of the software recommend $2 \mathrm{x}$ value at the edges and $4 \mathrm{x}$ value at the corners. The results hereinafter were obtained by this improved approximation.

In addition to the three types of approximated distributions, a fourth type was also considered, wherein the coefficient was calculated directly from the geotechnical numerical software. Due to the mesh density of the geotechnical model, the coefficients of subgrade reaction were determined using a $2 \mathrm{~m} \times 2 \mathrm{~m}$ grid as the ratio of bearing pressure and settlement at each point; thus, the distribution of subgrade reaction was produced 'artificially'. Accordingly, surface supports were defined in the structural finite element software with the same grid, but with half grid shift. Thus, a coefficient of subgrade reaction corresponding to a $2 \mathrm{~m} \times 2 \mathrm{~m}$ area was produced as the ratio of bearing pressure and settlement at the centre of that area. The average of the coefficient values is compared with the values of the modified Winkler method in 


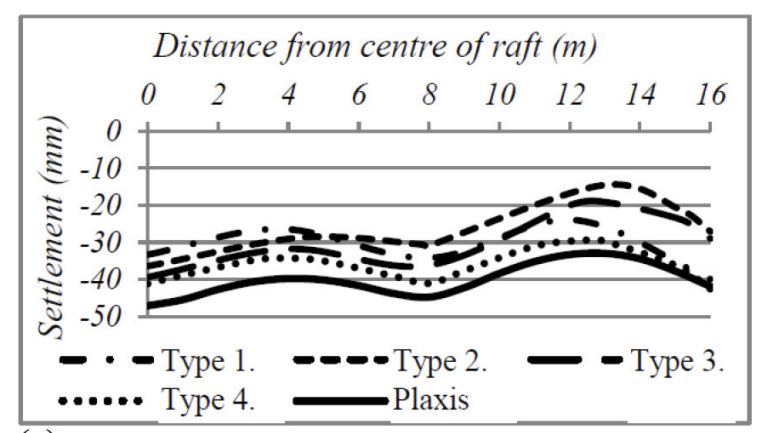

(a)

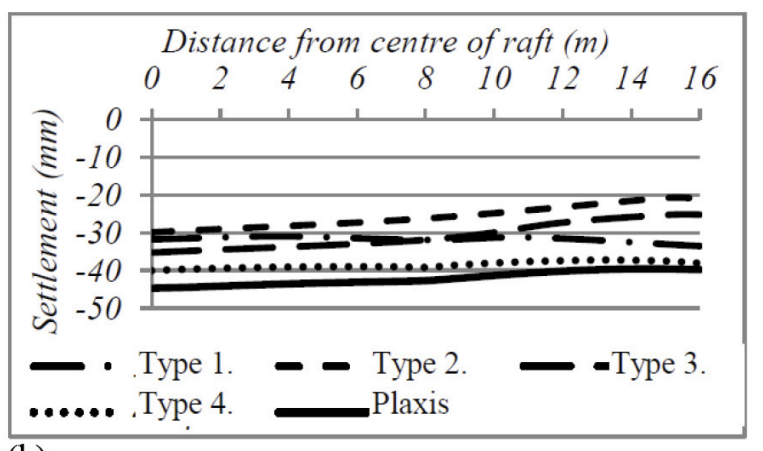

(b)

Figure 4: Settlement profile in the middle cross section of the raft, with raft thickness equaling (a) $0.40 \mathrm{~m}$ and (b) $1.00 \mathrm{~m}$.

Table 2. As the Winkler coefficient is independent of raft thickness, the coefficient values obtained from the geotechnical software were the average values calculated with different raft thicknesses to allow comparison of data (for the calculation, the 'Hardening Soil' model was used).

The two approaches give very similar results, and it can be also noted that the stiffer the soil, the better is the agreement between the two.

Settlement and moments in the middle cross section of the raft were compared to examine the influence of different distributions of subgrade reaction and values of raft thickness. Two values of raft thickness were selected: $40 \mathrm{~cm}$ to represent flexible behaviour and $100 \mathrm{~cm}$ to model a rigid foundation.

The study showed that for both flexible (Figure $4 \mathrm{a}$ ) and rigid rafts (Figure $4 \mathrm{~b}$ ), Type 4 distribution (which was calculated directly from the geotechnical numerical results) shows the best agreement; however, its displacement values are tendentiously smaller. The explanation behind this is the different modelling environments, as 'beam on elastic foundation' theory always gives smaller displacements than soil mass modelled as a continuum. Type 3 distribution has the most similar shape to Plaxis distribution, but its absolute values are considerably different. Previous findings are confirmed by Type 1 distribution (constant coefficient of subgrade reaction below the entire raft) as its shape only shows significant difference in the outer 2-3 m zone.

In case of clay, similar tendencies can be observed, but differences in the distributions are smaller because stiffer soils have a type of stress distributive property that decreases the role of subgrade in the settlement distribution. Considering the bending moments, again Type 4 distribution proved to be the best, correlating with the geotechnical finite element software results for different types of both soils and rafts (Figure 5). Type 1 distribution gives good approximation for both types of rafts in sandy gravel and for flexible raft in clayey soil, but for rigid raft in stiff soil, the deviation can be significant.

Based on the analysis of the different distributions, the following conclusions can be drawn:

- Distribution and absolute value of settlements and stresses determined by geotechnical finite element software can be approximated with 'beam on elastic foundation' theory if the resolution of subgrade is very detailed;

- In case of flexible raft and soft soil, distribution and values of bending moments calculated with constant coefficient of subgrade reaction throughout the entire surface show good correlation with the geotechnical numerical results (except at the negative peak moment values), but compared to the other part of the raft, it gives smaller settlements near the edges;

- In case of rigid raft and stiff soil, constant coefficient of subgrade reaction approximates poorly the results of geotechnical numerical runs.

- Considering the bending moments, the central section of the raft proved to be the most critical; differences in the results between subgrades and software products can be significant, especially for rigid rafts. 


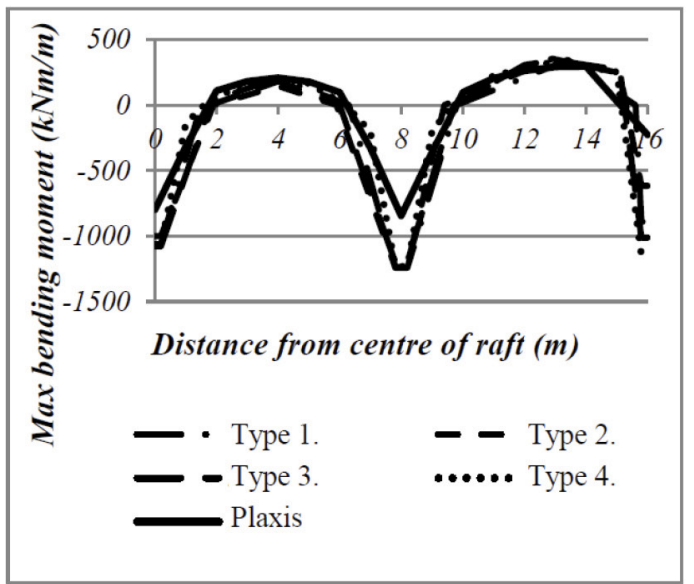

(a)

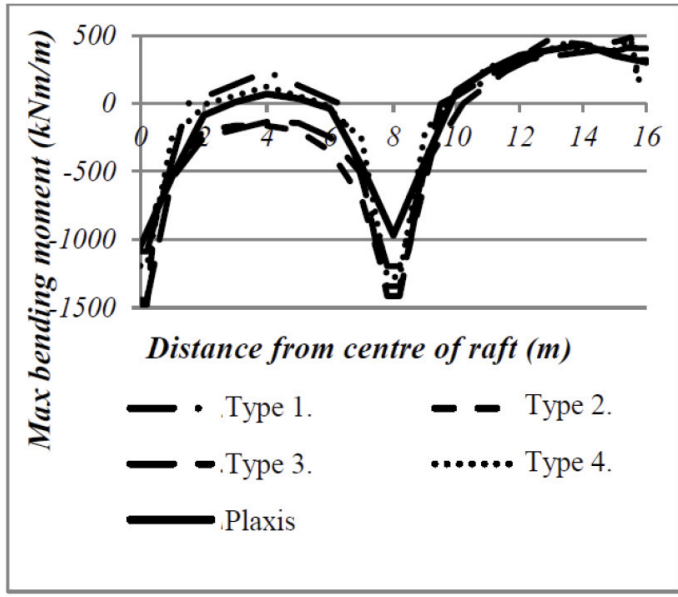

(b)

Figure 5: Bending moment $\left(m_{x}\right)$ in the middle cross section of the raft, with thickness equaling (a) $0.40 \mathrm{~m}$ and (b) $1.00 \mathrm{~m}$.

\section{Conclusion}

Based on the results, there is no significant difference between distributions of settlements, but displacements calculated with the geotechnical numerical software are tendentiously greater than the estimates of approximating methods, especially near the edge of the raft. Larger differences occur in terms of stresses and bending moments in the raft: peak moments are considerably smaller under the columns with geotechnical numerical software, so compared to this, the design based on 'beam on elastic foundation' theory can lead to oversizing. In the middle cross sections of the raft (especially for rigid rafts), large differences were observed between the different subgrades and between the different software products; moreover, the geotechnical finite element software mostly gave higher stresses. It was also noted that with structural software, the soil's ability for deformation has less influence on stresses than with the geotechnical software.

The analysis also confirmed that the distribution of coefficient of subgrade reaction is independent of soil type (and its properties); soil type only influences the absolute values of the coefficient. It was also noted that thickness of the raft (apart from very flexible rafts) for a given soil has no effect on the coefficient.

Calculation with the geotechnical finite element software showed that unlike the assumption in modified Winkler method (one-quarter of the width), the indirectly calculated coefficient of subgrade reaction only increases in a small strip (one-sixteenth of the width) at the edges. Aside from this section, the coefficient of subgrade reaction can be considered a constant. The herein-outlined results indicate that different modelling environments can cause significant differences in the analysis of the same problems. Therefore, the results of a parametric study in a given modelling environment may lead to incorrect results in another environment. A result of a concrete problem can be a good basis for another problem, but conclusions cannot be generalised. The goal of this study was not to decide which software gives the best result; it could be decided only with monitoring of real structures. However, it can be concluded that the commonly used simplified design methods contain approximations on the unsafe and uneconomical side; thus their revision is necessary.

\section{References}

[1] Terzaghi, K. (1955): Evaluation of coefficients of subgrade reaction. Geotechnique, 5, 297-326.

[2] Vesić, A. (1961): Beams on elastic subgrade and the Winkler's hypothesis. Proceedings of 5th International Conference on Soil Mechanics and Foundation Engineering, Vol. 1, pp. 845-850.

[3] Timoshenko, S., Goodier, J.N. (1970): Theory of Elasticity, 3rd edition. McGraw and Hill, New York.

[4] Bowles, J.E. (2001): Foundation Analysis and Design. McGraw-Hill, New Jersey.

[5] Larkela, A., Mengelt, M., Stapelfeldt, T. (2013): Determination of distribution of modulus of subgrade reac- 
tion. Proceedings of the 18th International Conference on Soil Mechanics and Geotechnical Engineering, Paris.

[6] Mayne, P.W., Poulos, H.G. (1999): Approximate displacement influence factors for elastic shallow foundations. Journal of Geotechnical and Geoenvironmental Engineering, ASCE, 125(6), 453-460.

[7] Abdullah, W.S. (2008): New elastoplastic method for calculating the contact pressure distribution under rigid foundations. Jordan Journal of Civil Engineering, 2 (1).

[8] Horvath, J.S., Colasanti, R.J. (2011): Practical subgrade model for improved soil-structure interaction analysis: model development. International Journal of Geomechanics, ASCE, 11(1), 59-64.

[9] Jagodnik, V., Jelenic, G., Arbanas, Z. (2013): On the application of a mixed finite-element approach to beam-soil interaction. Acta Geotechnica Slovenica, 10(2), 15-27.

[10] Mayne, P.W. (2005): Unexpected but foreseeable mat settlements on Piedmont residuum. International Journal of Geoengineering Case Histories, 1(1), 5-17.

[11] Móczár, B., Szendefy, J. (2013): Calculation of presumed bearing capacity of shallow foundations according to the principles of Eurocode 7 (in Hungarian). Vasbetonépítés, 2013(1), 20-26.
[12] Brinkgreve, R.B.J., Swolfs, W.M. (ed.) (2007): PLAXIS $3 D$ Foundation Version 2 Manual, PLAXIS BV, Delft, Netherlands.

[13] Van Langen, H. (1991): Numerical Analysis of Soil-Structure Interaction. PhD dissertation, Delft University of Technology, Delft, Netherlands.

[14] Egorov, K.E., Malikova, T.A. (1975): Settlement of foundation slabs on compressible base. Proceedings of 5th Asian Regional Conference on Soil Mechanics and Foundation Engineering, Bangalore, Vol. 1, pp. 187-190.

[15] Széchy, K., Varga, L. (1971): Foundations - Volume 1 (in Hungarian). Műszaki Könyvkiadó, Budapest.

[16] Dulácska, E., Fekete, S., Varga, L. (1982): Interaction of Sub Soil and Building (in Hungarian). Akadémiai Kiadó, Budapest.

[17] Axis VM 12: User's Manual Inter-CAD Kft [online]. Available on: http://axisvm.hu/axisvm_download_ training_materials.html

[18] Farkas, J. (1995): Foundation Engineering (in Hungarian). Műszaki Könyvkiadó, Budapest.

[19] Lopes, F.R. (2000): Design of raft foundations on Winkler springs, In: Hemsley, J.A. (ed.): Design applications of raft foundations, Thomas Telford Ltd., London, U.K, pp. 127-154. 